\title{
Virological examination of conjunctival swabs in clinically healthy horses
}

\author{
AGNIESZKA ŻAK, NATALIA SIWIŃSKA, BARBARA BAŻANÓW*
}

\begin{abstract}
Department of Internal Medicine and Clinic of Diseases of Horses, Dogs and Cats, Faculty of Veterinary Medicine, Wroclaw University of Environmental and Life Sciences, pl. Grunwaldzki 47, 50-366 Wroclaw, Poland

*Department of Pathology, Division Microbiology, Faculty of Veterinary Medicine,

Wroclaw University of Environmental and Life Sciences, ul. C. K. Norwida 31, 51-375 Wroclaw
\end{abstract}

Żak A., Siwińska N., Bażanów B.

Virological examination of conjunctival swabs in clinically healthy horses

\section{Summary}

The aim of the study was to determine the presence of the equine influenza virus (EIV), the equine arteritis virus (EAV), and the equine herpesvirus (EHV) in the conjunctival sac of clinically healthy horses. Fifty horses of both sexes and various breeds and ages were included in the study. Virus isolation was carried out in cell cultures (the Madin-Darby canine kidney, green monkey kidney and rabbit kidney cells) from conjunctival swabs. The hemaglutination assay was carried out in order to identify EI viral amplification. The study revealed no presence of the above listed viruses in the conjunctival sac of clinically healthy horses.

Keywords: equine arteritis virus, equine herpesvirus, equine influenza virus, horse, eye

All animal species as well as humans have bacterial and fungal commensal flora in the conjunctival sac (10). Literature reports the presence of fungi such as Aspergillus spp., Penicillium spp., Scopulariopsis spp. and Microsporum spp. in the conjunctival sac of clinically healthy horses (including newborn foals) $(1,10,15,17,19)$. Bacteria, including Streptococcus spp., Staphylococcus spp., Pseudomonas aeruginosa, Moraxella spp. and Corynobacterium spp., can also be isolated from the conjunctival sac of healthy horses (1, $10,11)$. These bacteria exacerbate ulcerative keratitis $(1,10,11,16)$. The identification of the commensal microbiota in the conjunctival sac of horses is essential for a correct diagnosis. There have been no reports to date of the isolation and culture of viruses from the conjunctival sac in healthy horses. The most common viral ophthalmic pathogen in horses is the Herpesviridae group (6). Equine herpesvirus-1, belonging to the alpha-herpesviruses group, in addition to respiratory, nervous and reproductive disorders, may be the cause of retinopathy (8). Viruses belonging to the gammaherpesviruses group are mainly responsible for viral keratitis in horses (8). Moreover, equine herpesvirus type 2 has an affinity for conjunctival epithelial cells (4). Other viruses can also cause conjunctivitis in horses: Equine Arteriritis Virus (EAV), Equine Influenza Virus (EIV) or less frequently adenoviruses $(2,3,6,7)$. The most common ocular signs include eye discharge (mucous to purulent), redness and conjunctival oedema and photophobia (6).

The aim of the study was to determine whether viruses responsible for ocular and upper respiratory tract disease (EHV, EIV, EAV) can be isolated from the conjunctival sac of clinically healthy horses.

\section{Material and methods}

The study was carried out on 50 horses of both sexes, from eight months to 27-years-old from two equestrian facilities in central and southern Poland. The owners gave informed consent prior to sample collection. In accordance with the Polish law, this study did not require the approval of the Ethical Committee (Experiments on Animals Act from January $15^{\text {th }} 2015$, Journal of Laws of the Republic of Poland from 2015, item. 266). The owners of the horses had been asked to provide a history of ocular disease prior to sample collection. Clinically healthy horses that did not have a history of ocular disease or infectious diseases (such as equine influenza) one year prior to study entry were chosen. All of the horses included in the study had been regularly vaccinated against the equine influenza virus (EIV) and tetanus (Equilis Prequenza Te, Intervet International BV, Netherlands). An ophthalmological examination was carried out in each horse and included an examination of the ocular adnexa, eyesight and the pupillary light reflex assessment and an indirect ophthalmoscopic examination. Horses with an ocular discharge, skin maceration in the medial canthal area, a reddened conjunctiva, conjunctival 
edema and other ophthalmic pathologies were withdrawn from the study. The clinical examination and the swab collection were carried out by a qualified veterinary surgeon on an animal in standing position and without pharmacological sedation. Swabs were collected without topical anaesthesia. The specimens were collected from the left conjunctival sac using sterile viscose swabs (Citoswab, Citotest Labware Manufacturing Co, China), which were moved along the lower eyelid margin from the middle to the lateral canthus of the eye and from the anterior surface of the third eyelid, by retropulsing the globe through the upper eyelid and everting the lower eyelid to expose the anterior surface of the third eyelid $(7,12)$. Aseptic precautions were taken so that the eyelid skin, eyelids, eyelashes or vibrissae were not swabbed. Immediately after collection, the swab sticks were put into tubes containing MEM (Minimal Essential Medium) with antibiotics. The specimens were refrigerated and transported to the laboratory within an hour of collection. Virological examination was performed in the Laboratory of Department of Microbiology, Wrocław University of Environmental and Life Sciences according to the virological guidelines (20). Individual swab sticks were gently pressed against the wall of the tubes and discarded (OIE: Manual of Diagnostic Tests and Vaccines for Terrestrial Animals 2016, http://www.oie.int/manual-of-diagnostictests-and-vaccines-for-terrestrial-animals/). The medium was centrifuged at $1500 \mathrm{~g}$ for 15 minutes to remove bacteria and debris and inoculated separately $(50 \mu 1$ per well, 2 replicates per sample) into different cell lines: the Madin-Darby canine kidney (MDCK (NBL-2) (ATCC No CCL-34 ${ }^{\mathrm{TM}}$ ) was used to isolate the equine influenza virus (EIV), the rabbit kidney cells (RK-13 ATCC No CCL-37 ${ }^{\mathrm{TM}}$ ) were used to isolate the equine arteritis virus (EAV) and the type 1 equine herpesvirus (EHV1), type 2 equine herpesvirus isolation (EHV2), type 5 equine herpesvirus (EHV5) and the green monkey kidney (Vero - ATCC No CCL-81 ${ }^{\mathrm{TM}}$ ) was used to isolate $\mathrm{EAV}$, seeded in 96-well polystyrene plates the day before inoculation. The plates were incubated at $37^{\circ} \mathrm{C} / 5 \%$ $\mathrm{CO}_{2}$ and observed daily for 10 days for the occurrence of the cytopathic effect (CPE). In the case of EAV up to four blind passages were done. Supernatants from the MDCK cell cultures were also repasaged and then harvested and assayed for hemagglutination (HA). Reference strains of EAV (Bucyrus), EHV1 (RacH) and EIV (Alequine/Prague/56 (H7N7) and A/Equi-2/Miami/63 (H3N8)) were used as positive controls.

\section{Results and discussion}

The examined viruses were not isolated in any cell line in any passage. Similarly, the results of the HA in the tested samples were negative. No further molecular characterization was carried out due to the lack of virus isolation.

Virus isolation in cell cultures is a specific and highly sensitive method that confirms the presence of the virus in the examined material (13). However, this method is not widely used in ophthalmological diagnostics due to its duration. The results of our study suggest that there was no present or past ocular disease in the studied clinically healthy horses. Furthermore, there were no isolated EHV-1, EHV-2, EHV-5, EIV, EAV in the commensal form in the conjunctival sac of those horses in our study. The authors attempted to isolate and culture the viruses and assess the CPE on a cell line in order to determine the presence of multiple viruses in the conjunctival sac. Previous studies have shown the presence of antigens in the form of EHV-2 and EHV-5 DNA in the conjunctival sac in horses with keratoconjunctivitis as well as in healthy controls, detected using the qPCR method $(4,5,9,14,16)$. This indicates that some types of latent herpesviruses may be present in the conjunctival sac of clinically healthy horses which, according to Rushton et al., is not always associated with ocular disease (16). In the study of Creig at al. a virus neutralization test showed a total of $79.7 \%$ healthy horses were sero-positive for EHV-2 (5). In case of herpesviruses, the phenomenon of latency and localization of the virus is characteristic in clinically healthy individuals in the nerve endings (alpha-herpesviruses) and lymph nodes (gammaherpesviruses). These viruses are activated only in the case of a decrease in immunity $(8,14)$. Therefore, despite the presence of the virus in the body, it may be not detected in conjunctival or eyelid swabs. In literature, equine influenza virus, equine arteritis virus or their DNA has not been found in the conjunctival sac in clinically healthy horses. Our results and the literature review suggest that the isolation of the EIV or EAV from the conjunctival sac in sick horses may indicate a viral cause of their disease. The results of the equine herpesvirus isolation should be carefully interpreted. Further studies focusing on one type of virus are warranted. Hypothetically, viruses known to cause ocular disorders may be isolated in the case of subclinical infections that occur without clinical signs. A re-examination was carried out in the studied group two weeks after sample collection and the owners did not report any abnormalities.

\section{References}

1. Andrew S. E., Nguyen A., Jones G. L., Brooks D. E.: Seasonal effects on the aerobic becterial and fungal conjunctival flora of normal thoroughbred brood mares in Florida. Vet. Ophthalmol. 2003, 6, 45-50.

2. Aroch I., Ofri R., Sutton G. A.: Objawy okulistyczne chorób układowych, [in:] Maggs D. J., Miller P. E., Ofri R. (ed.): Okulistyka weterynaryjna Slattera. Saunders Elsevier, Wrocław 2009, p. 412-461.

3. Bazanow B. A., Jackulak N. A., Fracka A. B., Staroniewicz M. E.: Abortogenic viruses in horses. Equine Vet. Educ. 2014, 26, 48-55.

4. Borchers K., Ebert M., Fetsch A., Hammond T., Sterner-Kock A.: Prevalence of equine herpesvirus type 2 (EHV-2) DNA in ocular swabs and its cell tropism in equine conjunctiva. Vet. Microbiol. 2006, 118, 260-266.

5. Craig M. I., Barrandeguy M. E., Fernandez F. E.: Equine herpesvirus 2 (EHV-2) infection in thoroughbred horses in Argentina. BMC Vet. Res. 2005, 1,9 .

6. Davis J. L.: Ocular Manifestations of Systemic Disease, [in:] Gilger B. C. (ed.): Equine Ophthalmology. Saunders Elsevier, Missourii 2011, p. 443-465.

7. Giuliano A. E., Moore C. P.: Eyes and ocular adnexa, [in:] Cowell R. L., Tyler R. D. (ed.): Diagnostic Cytology and Hematology of the Horse. Mosby, Missourii 2002, p. 43-64

8. Gonzales-Medina S.: The role of equine herpesviruses in ocular disease: An incidental finding or a pathogen? Equine vet. Educ. 2015, 27, 623-626.

9. Hollingsworth S. R., Pusterla N., Kass P. H., Good K. L., Brault S. A., Maggs $D$. J.: Detection of equine herpesvirus in horses with idiopathic keratocon- 
junctivitis and comparison of three sample technik. Vet. Ophthalmol. 2015, $18,416-421$

10. Johns I. C., Baxter K., Booler H., Hicks C., Menzies-Gow N.: Conjunctival bacterial and fungal flora in healty horses in the UK. Vet. Ophthalmol. 2011, 14, 195-199.

11. Keller R. L., Hendrix D. V. H.: Bacterial isolates and antimicrobial susceptibilities in equine bacterial ulcerative keratitis (1993-2004). Equine Vet. J. 2005, 37, 207-211

12. Maggs D. J.: Podstawowe techniki diagnostyczne, [in:] Maggs D. J., Miller P. E., Ofri R. (ed.): Okulistyka weterynaryjna Slattera. Saunders Elsevier, Wrocław 2009, p. 88-116.

13. Oaks L. J.: Laboratory Diagnosis of Viral Infections, [in:] Sellon D. C. (ed.) Equine Infectious Diseases. Saunders Elsevier, Missourii 2007, p. 116-124.

14. Richter N., Ebert M., Borchers K.: Prevalence of EHV-2 and EHV-5 DNA in ocular and nasal swabs as well as peripheral blood mononuclear cells. Pferdeheilkunde 2009, 25, 38-44.

15. Rosa M., Cardozo L. M., Pereira J. S., Brooks D. E., Martins A. L. B., Florido P. S. S., Stussi J. S. P.: Fungal flora of normal eyes of healthy horses from the State of Rio de Janeiro, Brazil. Vet. Ophthalmol. 2003, 6, 51-55.
16. Rushton J. O., Kolodziejak J., Tichy A., Nell B., Nowotny N.: Detection of equid herpesviruses 2 and 5 in a herd of 266 Lipizzaners in association with ocular findings. Vet. Microbiol. 2013, 164, 139-144.

17. Sauer P., Andrew S. E., Lassaline M., Gelatt K. N., Denis H. M.: Changes in antibiotic resistance in equine bacterial ulcerative keratitis (1991-2000): 65 horses. Vet. Ophthalmol. 2003, 6, 309-313.

18. Sgorbini M., Barsotti G., Nardoni S., Mancianti F., Rossi S., Corazza M.: Fungal flora of normal eyes in healthy newborn foals living in the same stud farm in Italy. J. Equine Vet. Sci. 2008, 28, 540-543.

19. Sousa M. E., Araujo M. A., Mota R. A., Porto W. J. N., Souza A. K. P., Santos J. L., Silva P. P.: Fungal microbiota from ocular conjunctiva of clinically healthy horses belonging to the military police cavalry of Alagoas. Brazil J. Microbiol. 2011, 42, 1151-1155.

20. Timoney J., Gillespie J. H., Scott F. W., Barlough J. E.: Laboratory Diagnosis of Viral Infection, [in:] Hagan and Bruner's Microbiology and Infectious Diseases of Domestic Animals. Cornell Univ. Press: Ithaca, New York 1988, p. 467-468.

Corresponding author: Agnieszka Żak, DVM, pl. Grunwaldzki 47, 50-366 Wroclaw, Poland; e-mail: agnieszka.zak@upwr.edu.pl 